\title{
Platelet-rich fibrin to manage different periodontal defects combine with Flap surgery and other uses in dentistry. A descriptive review
}

\author{
Md. Ashif Iqbal ${ }^{{ }^{*}}$,Marjana Hossain Mim², Nayna Binte Shahabuddin ${ }^{3}$
}

AFFILIATION:

1. Md. Ashif Iqbal

Associate Professor \& Head

Dept. of Periodontology \& Oral Pathology

Update Dental College, Dhaka, Bangladesh

Email:drasif100@gmail.com

ORCID Id: https://orcid.org/0000-0002-9490-7927

2. Marjana Hossain Mim

Intern Doctor

Dept. of Periodontology \& Oral Pathology

Update Dental College, Dhaka, Bangladesh

Email: marjanahossainmim@gmail.com

ORCID Id:https://orcid.org/0000-0001-7173-9249

3. Nayna Binte Shahabuddin

Lecturer,

Dept. of Periodontology \& Oral Pathology,

Update Dental College, Dhaka, Bangladesh

Email: naynabstuba30@gmail.com

ORCID Id: https://orcid.org/0000-0002-7906-5645

Article info.

Received: 09 April 2021

Accepted: 17 July 2021

Volume: Vol-11, Issue-2, October 2021

DOI:https://doi.org/10.3329/updcj.v11i2.56130



CAuthorsretaincopyrightandgrantthejournalrightoffirst publication with the work simultaneously licensed under CreativeCommonsAttributionLicenseCC-BY4.0thatallows others to share the work with an acknowledgment of the work'sauthorshipandinitialpublicationinthisjournal.

https://creativecommons.org/licenses/by/4.0/

Publisher: Update Dental College, Dhaka, Bangladesh

Web:www.updatedentalcollege.edu.bd

E-mail: updcj@hotmail.com

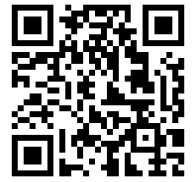

Scan QR code to see the latest issue

* Corresponding Author

Md. Ashif Iqbal

Associate Professor \& Head

Depr. Of Periodontology \& Oral Pathology

Update Dental College, Dhaka, Bangladesh

Email: drasif100@gmail.com

ORCID Id:https://orcid.org/0000-0002-9490-7927

Cell: +8801716116080

\section{ABSTRACT:}

In these days, periodontal diseases are very much common in Asian subcontinent especially in Bangladesh, due to some relevant factors that is more prevalent in this country. Most of the time patient neglect their condition and ultimately loss their teeth. Even after doing phase 1 therapy that is scaling, polishing with antimicrobial agents, it could not heal the periodontal condition with advanced bone destruction or clinical attachment loss. Therefore, after proper oral hygiene maintenance therapy, different flap surgery should consider. . In recent study, it is found that platelet rich fibrin (PRF) PREPARED From the patient's Own blood and then placement within defect could enhance the early healing procedure. This PRF membrane is also used in a variety of discipline in dentistry, including regenerative surgery. This PRF membrane is now used in a variety of disciplines in dentistry, including regenerative surgery and enhancing early healing. The goal of this study is to critically analyze and appraise the currently available research with an emphasis on the use of PRF in regenerative periodontal surgery.

An electronic search was conducted (PubMed/MEDLINE, Google Scholar, BanglaJOL, Cochrane library). Various combinations of the following keywords were used: 'prf', 'prf membrane', 'periodontal regenerative surgery', 'prf in dentistry', 'systemic diseases and periodontitis', 'drawback of prf', 'plateletderived growth factors', 'prf in oms', 'prf in orthodontics'. Articles were searched until August 2021

All of these studies reveal that the PRF membrane enhances the healing of various defects in a variety of periodontal diseases and in several fields of dentistry. Studies are going on pulp regeneration and socket healing after extraction with PRF in dentistry. More emphasis should have to give to the prevention of periodontal diseases as well as more concern should have to give on PRF with flap surgery to enhance healing and improve the social health of the general population by preventing tooth loss and for different research purposes on PRF in different other fields of dentistry in Bangladesh.

KEYWORDS: platelet-rich fibrin, prf membrane, prf preparation, periodontal disease, flap surgery

\section{INTRODUCTION:}

Bangladesh is one of the densely populated countries in this world. Total population around 165 million in 2020 (1) and ranked position $8^{\text {th }}$ in the world. (2) People are suffering from multiple systemic diseases as well as dental diseases here. Because of poor oral hygiene practices, betel quid chewing \& complication of different systemic diseases, periodontal diseases become more prevalent among all dental problems in Bangladesh. (3-5) This type of patient is commonly treated here by phase-1 nonsurgical therapy mainly by scaling, polishing, and oral hygiene instructions and given antimicrobial therapy. (6) flap surgery is indicated if the periodontal condition is not improved by non-surgical periodontal therapy. Different grafts like Xenogenic collagen matrix, autologous connective tissue graft or enamel matrix derivatives etc. as an adjunct to different advanced flaps surgery are utilized to enhance the healing. (712)Platelet-rich fibrin (PRF) is a second-generation autologous platelet concentration that is obtained from the patient's blood in a simple and cost-effective manner. (13) Platelet-rich fibrin (PRF), as described by Choukroun et al, was initially used in clinical practice in Southern Europe in oral maxillofacial and 
implant surgery. (14) It was created as a less expensive, but more biocompatible and effective, alternative to platelet-rich plasma (PRP) for bone and soft tissue regeneration. PRF is less soluble after administration than PRP needs less biochemical blood processing, and offers a longer-lasting release of platelet cytokines and growth factors.

\section{BACKGROUND HISTORY OF PRF:}

Platelets have been used as useful tools for periodontal regeneration for over two decades due to their important role in the wound healing process. Although the use of fibrin adhesives has been well documented over the last 30 years $(16,17)$, their use remains controversial due to the difficulty in preparation and the risk of cross-infection. Following that, a less complex production protocol was used to create concentrated platelet-rich plasma (cPRP). It is made from the patient's blood and is activated with thrombin and calcium. The structure is made up of a three-dimensional biocompatible fibrin scaffold and a small volume of plateletenriched plasma. Growth factors and proteins are released into the immediate environment when PRP is activated,(18) facilitating postoperative wound healing and tissue regeneration. However, the downside of employing PRP is that its qualities can vary based on platelet concentration, leukocyte count, activator type, and time of fibrin scaffold insertion after clotting. (19) However, there are some hazards linked with PRP use. The presence of bovine thrombin in PRP can lead to the formation of antibodies to the clotting factors $\mathrm{V}, \mathrm{XI}$, and thrombin, which can cause the coagulation process to be disrupted. Furthermore, when challenged with a foreign protein, bovine thrombin preparations contain clotting factor $\mathrm{V}$, which might cause immune system activation. Other disadvantages of PRP use include permissible requirements on handling blood, as well as literary disagreements concerning the benefits and clinical outcomes of PRP use.

All of this has resulted in the development of platelet-rich fibrin, a novel type of platelet concentrate that solves many of the drawbacks of PRP. PRF is a powerful autologous regenerative substance that has a wide range of clinical applications in periodontics, as it promotes both soft and hard tissue regeneration.(20). Other than PRF there are certain growth factors also used in Dentisrry like: Enamel Matrix Derivatives, Platelet-Derived Growth factor, Bone Morphogenic Proteins, Platelet rich plasma but Platelet rich Fibrin proven success in variety of Dental procedures and easily obtainable. (21)

\section{PRF PREPARATION:}

Dr. Choukroun(22) invented the traditional PRF preparation technique in 2000. It is the current PRF technique approved by the French Ministry of Health, in which PRF is prepared without the use of an anticoagulant during blood collection or

44| P a g e bovine thrombin during gelling. (23)

To obtain the proper quantity and quality of fibrin matrix, leukocytes, platelets, and growth factors, a standard protocol for PRF preparation should be followed. A PC-02 table centrifuge(24) and a blood collection kit consisting of a 24 gauge butterfly needle and $9 \mathrm{ml}$ blood collection tubes are required for PRF preparation. A blood sample is collected from the patient without anticoagulant in $10 \mathrm{ml}(24)$ tubes and immediately centrifuged at $3000 \mathrm{rpm}$ for 10 minutes. (20)(25) or for 12 minutes $(24,26,27)$ The typical PRF preparation is centrifuged for 12 minutes at $2700 \mathrm{rpm}$, while the advanced platelet-rich fibrin (A-PRF) is centrifuged for 14 minutes at $1500 \mathrm{rpm}$, according to some reports.(28)

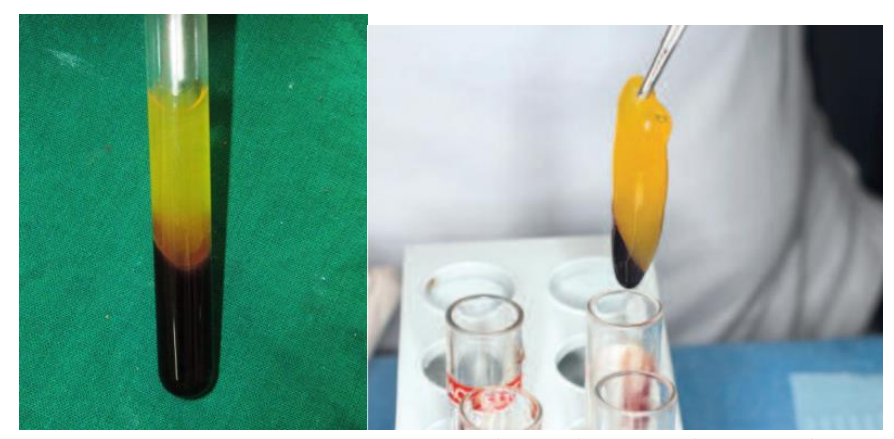

Figure 1: Test tube showing Platelet-rich fibrin after centrifugation of blood, PRF membrane being withdrawn from the blood tube.

When blood comes into touch with the test tube wall during centrifugation, platelets get activated, causing the coagulation cascade to begin. The final product is made up of three layers after centrifugation. (14)

Acellular PPP (platelet-poor plasma) is on top, followed by a PRF clot in the middle, and RBCs at the bottom of the test tube. After centrifugation, the fibrin clot is removed from the tube, and the associated red blood cells are scraped off and discarded. By squeezing out the fluids in the fibrin clot, PRF can also be made in the form of a membrane.

Mito Kobayashi et al (29) have been suggested the stainless steel PRF compression device, created for PRF membrane preparation is made up of two spoon-shaped pieces. Many pinholes were included in the stage where the PRF clot was put for fastening the clot and draining excess fluid from the serum when the clot was compressed. The clearance between the spoon pieces was increased to $1 \mathrm{~mm}$. As a result, a standard 1$\mathrm{mm}$ thick PRF membrane was consistently prepared when the PRF clots were squeezed with this equipment. (Figure-2)

Website: https://www.banglajol.info/index.php/UpDCJ 

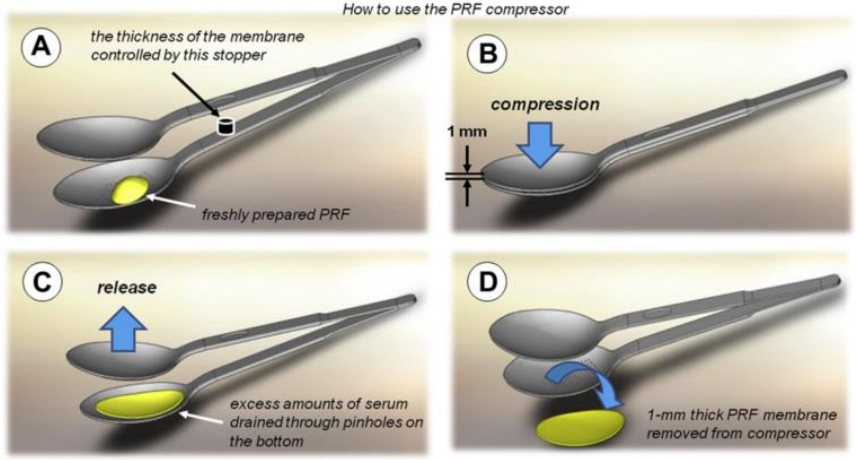

Figure-2: Appearance of the PRF compressor and the protocol for operation. The PRF clot is placed on the lower spoon, which possesses many pinholes (A), and is compressed by pushing the handles together (B). In this step, excess amounts of exudates would be removed. The compression force is then released (C), and the resulting 1-mm thick PRF membrane is removed (D). (This figure has been collected from an article By Mito Kobayashi et al (29) was published in the journal of Biologicals, Volume 40, Issue 4, September 2012, Pages 323-329 under open access policy with Creative Commons AttributionNonCommercial-No Derivs (CC BY-NC-ND) \& CC BY Licence. (30)

Some author suggest The L-PRF Wound Box for the preparation and standardization of PRF in clots and membranes. The membrane in the clots is compressed using the PRF Wound Box in a slow and homogeneous minor compression, ensuring that the final membrane is always uniformly moist and soaked in serum. (31)

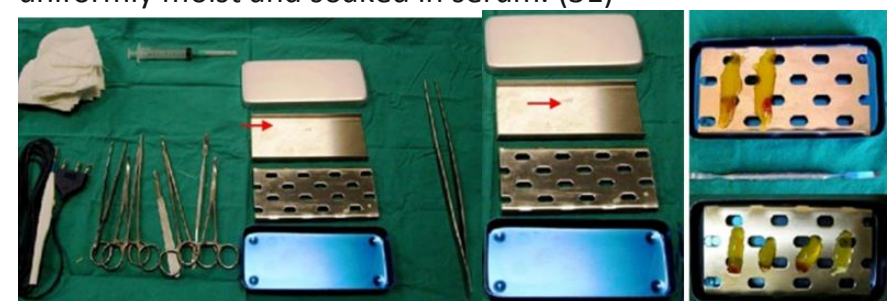

Figure: 3 : L-PRF Wound Box. (This figure has been collected from an original article By byAlessandro Crisci et al(31)was published in the Journal of Unexplored Medical Data published on 22 Nov 2017, under open access policy with Creative Commons Attribution (CC BY-4) License.(32)

The amount of time between blood collection and the centrifugation process is an essential factor in the procedure's success and clinical outcome. Because blood is handled slowly throughout the centrifugation process, diffuse polymerization of fibrin occurs, resulting in the creation of a tiny blood clot with uneven consistency. As a result, a PRF technique that is repeatable has been developed.

\section{MECHANISM OF ENHANCING HEALING:}

Platelets taken from the blood serve as an autologous resource of growth factors. Platelet concentrate generated from blood can be used in general medical practice to prevent and manage bleeding caused by disorders such as severe thrombocytopenia, severe oral hemorrhage associated with medullary aplasia, acute leukemia, and so on. (33)Platelet concentration as a bioactive surgical addition is being

45| P a g e developed with the help of fibrin adhesives. Since 1990, certain blood components have been identified as being a part of the natural healing process and having the ability to speed wound healing when administered to wounded tissues or surgical sites. The first description of fibrin glue, which is made by polymerizing fibrinogen with thrombin and calcium, was in 1970. It was made with donor plasma, but due to the low concentration of fibrinogen in plasma, the durability and quality of the fibrin glue were poor. (34) These fibrin adhesives can be obtained either autologously from the patient or commercially, however, the latter carries a slight risk of disease transmission.

Platelet-rich fibrin (PRF), a second-generation platelet-rich aggregation, is easy to make and releases cytokines gradually as it degrades. (35) As a result, PRF has a high capacity for wound healing and tissue regeneration. $(36,37)$ PRF greatly enhances the osteogenic potential of BMSC membranes in nude mice, and a rabbit skull defect model revealed a synergistic effect of PRF and osteoblastic bone marrow mesenchymal stem cells (BMSC) membranes on bone defect repair. (38) The cytokine stimulation and fibrin scaffolding effects of PRF on tissue repair are principally responsible. TGF1, insulin-like growth factors (IGFs), vascular endothelial growth factor (VEGF), and platelet-derived growth factors (PDGFs) are the most common cytokines found in PRF. They effectively recruit cells that are important for tissue repair to defect sites and then promote and regulate the tissue repair process. $(35,39)$ Furthermore, PRF fibrin offers a threedimensional framework that encourages recruited cells to proliferate and differentiate. (40) PRF has been effectively utilized to treat bone and cartilage defects, dental implants, and severe periodontitis, with significant treatment outcomes. $(41,42)$

\section{CLINICAL APPLICATION OF PRF IN DENTISRY :}

PRF membrane can be utilized for a variety of applications in dentistry.

\section{A. PRF IN PERIODONTAL DISEASES:}

It can be used for correction of different types of gingival recession $(43,44)$, The most predictive plastic surgery is a coronally advanced flap procedure with subepithelial connective tissue. PRF has recently been utilized in conjunction with traditional order to improve the efficacy of root coverage treatments while lowering morbidity.(45) According to Aroca et al. (46) when compared to the modified coronally advanced flap alone, the use of PRF membrane resulted in an increase in the width of keratinized gingiva at the test sites after 6 months.

Gabriel Merizalde et al. has showed one successful surgical case with utilization of PRF in in 33, 34 teeth and improvement of clinical attachment loss from $5 \mathrm{~mm}$ to $3 \mathrm{~mm}$ within next 3

Website: https://www.banglajol.info/index.php/UpDCJ 
months (Figure-4) (25), Anilkumar et al.(45) also demonstrated that six months after using a laterally repositioned flap in conjunction with PRF to cover a localized recession on the buccal side of a mandibular incisor, complete root coverage was achieved with excellent tissue contour and color, demonstrating that this fibrin biomaterial has potential for use in periodontal surgeries.



Figure -4: Gingival recession located 33 and 34 buccal surfaces, -PRF membranes placed on gingival recession Clinical appearence six months after surgery (This figure has been collected from an article By byGabriel Merizalde et al(25). was published in the International journal of odontostomatologyVolume 13, no-1, March 2019, under open access policy with Creative Commons Attribution (CC BY-NC) License.(63)
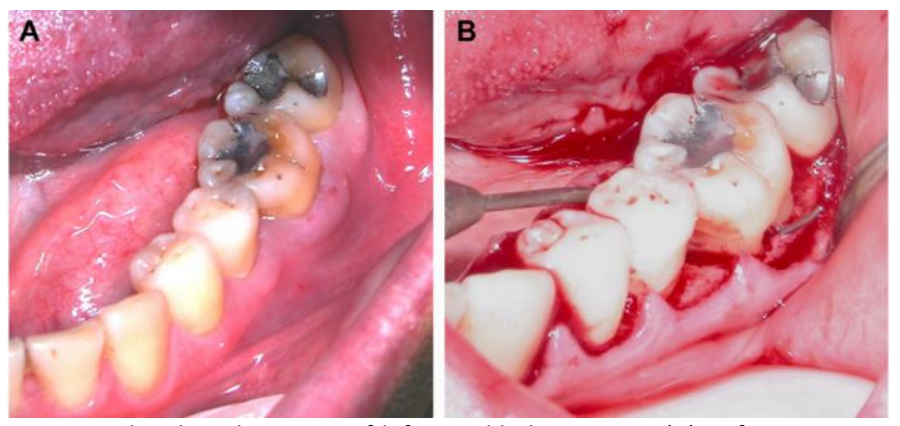

Figure-5: The clinical pictures of left mandibular sextant. (A) Before surgery. (B) After flap reflection, mesial infrabony defect and a through-and-through furcation invasion were noted at \#36. (This figure has been collected from a case report By Yu-Chao Chang et al. (24) was published in the Journal of Dental Sciences, Volume 6, Issue 3, September 2011, Pages 181-188 under open access policy with Creative Commons Attribution-NonCommercial-NoDerivs (CC BY-NC-ND) license. (https://www.elsevier.com/journals/journal-ofdental-sciences/1991-7902/open-access-journal) (64)

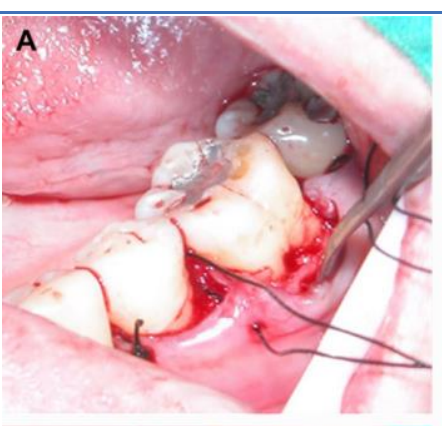

Md. Ashif Iqbal et al.
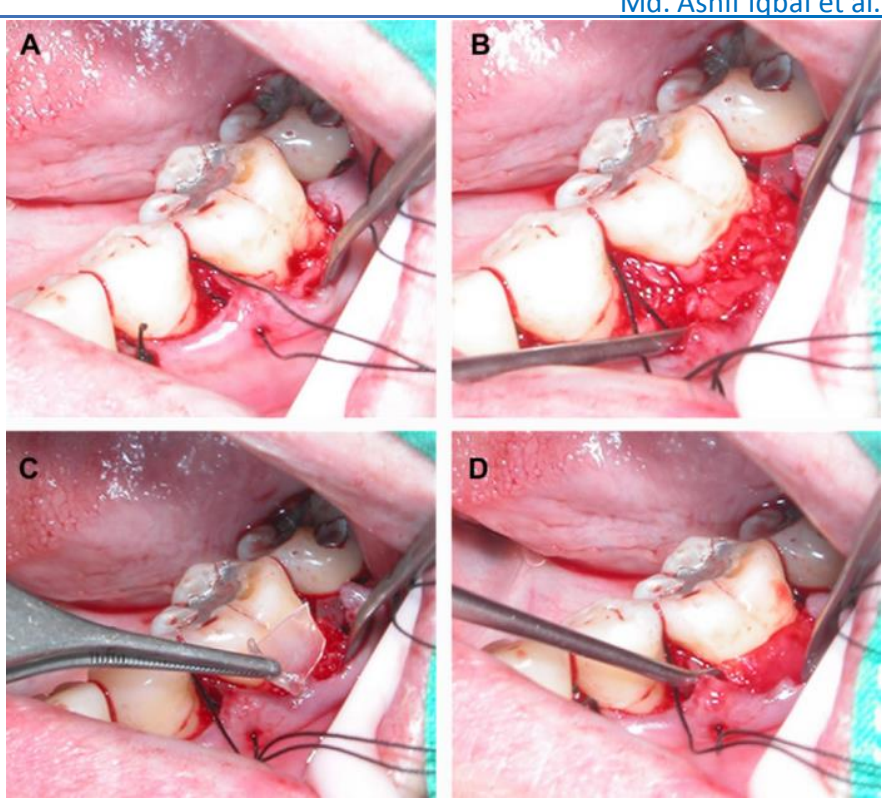

Figure: 6- Clinical application of platelet-rich fibrin (PRF) on the buccal aspect of \#36. (A) Minced PRF was applied to the defect walls and root surfaces. (B) Minced PRF was tightly packed in the furcation area. (C) PRF membrane was trimmed to cover the osseous defects. (D) PRF membrane was adapted over the grafted defect and above the cementoenamel junction by Yu-Chao Chang et al. (This figure has been collected from a case report By Yu-Chao Chang et al. (24) was published in the Journal of Dental Sciences, Volume 6, Issue $\underline{3}$, September 2011, Pages 181-188 under open access policy with Creative Commons Attribution-NonCommercial-NoDerivs (CC BY-NC-ND) license. (https://www.elsevier.com/journals/journal-of-dental-sciences/1991-
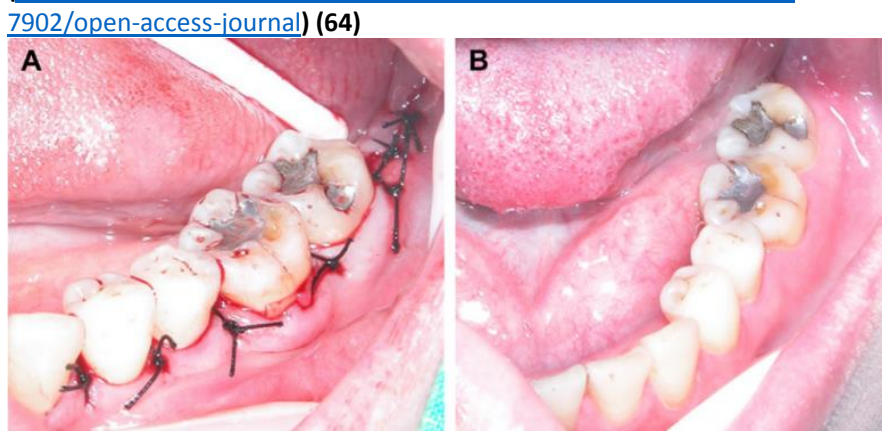

Figure: 7 : The clinical pictures after platelet-rich fibrin application. (A) The flaps were repositioned to their presurgical levels and sutured with silk utilizing an interrupted technique. (B) The clinical picture of \#36 3 months after operation. (This figure has been collected from a case report By Yu-Chao Chang et al. (24) was published in the Journal of Dental Sciences, September 2011, under open access policy with Creative Commons AttributionNonCommercial-NoDerivs (CC BY-NC-ND) license. (https://www.elsevier.com/journals/journal-of-dental-sciences/19917902/open-access-iournal) (64)

PRF also used in treating furcation defect in chronic periodontitis (47-49), in generalized aggressive periodontitis(50),for correction of intrabony defect(51-55), to prevent osteoclastic effect and thus help in periodontal bone regeneration(56-62)Clinical application of platelet-rich fibrin as the sole grafting material in periodontal intrabony defects by Yu-Chao Chang et al. (24)has showed a succesfull outcome. Figure: 5,6,7 
B: PRF IN ORAL AND MAXILLOFACIAL SURGERY:

PRF membrane can be used for management of dry socket (65), Sam Paul et al have found platelet-rich fibrin better than zinc oxide eugenol in cases of established dry socket for controlling pain, reducing inflammation, and improving wound healing.(66) PRF also used for better healing and bone regeneration after extraction $(67,68)$, to enhances soft tissue support and regeneration after surgery (69),for improving bone growth around dental implant (70) and to increase the width of keratinized mucosa around implants (71), accelarte early implant placement after PRF placement in extracted socket(72) and also healing of periodontal tissue and bone regeneration after infected radicular cyst enucleation $(73,74)$. Also used in medication related to Osteonecrosis of the jaw. (75)

\section{C: PRF IN ENDODONTICS:}

PRF membrane can be used for pulpal regeneration and tooth revitalization (76),for apexogenesis in young permanent tooth (77), management of perforation in furcation regeneration followed by endodontic treatment (78)

D: PRF IN PERIO-ENDO LESIONS:

Periodontal lesions spread apically with an already existing periapical lesion, or an endodontic lesion combines with an existing periodontal lesion to form perio-endo lesions. A true combined perio-endo lesion's prognosis is frequently poor or even hopeless, especially if it is chronic. Increased bony support through bone grafting and guided tissue regeneration, as well as the introduction of polypeptide growth factors to the surgical area, can enhance the prognosis of such afflicted teeth.(79) El-Sharkawy et al. (80) proposed using PRF in conjunction with tissue regeneration techniques to treat intrabony defects in such a case.

\section{E: PRF IN PEDIATRIC DENTISTRY:}

One article by Priya Nagar and Deppak Viswanath has mention in their review article regarding uses of PRF in Pediatric dentistry specially in Pulp capping, Pulpotomy and Apexogenesis and also in extracted socket. (81)

F: PRF AND PERIODONTALLY ACCELERATED OSTEOGENIC ORTHODONTICS

Periodontally Accelerated Osteogenic Orthodontics (PAOO) is a procedure that combines orthodontic forces with cortcotomies and alveolar bone plate grafting to enhance tooth movement. A case report of a patient with a high buccal canine and bimaxillary protrusion where PRF was used alongside other treatment modalities has also been presented in the literature. This was thought to improve healing after a segmental osteotomy and a single tooth cortcotomy around the canine, both of which were performed under local anaesthesia. According to the authors, this resulted in a decrease in canine retracton time.(82)

47| P a g e
DRAWBACKS OF PRF MEMBRANE:

Md. Ashif lqbal et al.

Over time, one of the reported disadvantages included its use of anticoagulants or known inhibitors of clot formation. Thus decreasing the long-term release of growth factors and ultimately diminishing its regenerative potential. It resorbs in around 7 days,(83) which is far faster than the $4-6$ weeks (84) necessary for conventional periodontal regeneration procedures. Another big downside of PRF is its preservation after it has been prepared.PRF membrane should also be used as soon as possible after preparation because they can shrink, causing dehydration and undermining the structural integrity of PRF. $(20,85)$

\section{DISCUSSION :}

PRF is now well eastablished regenrative materials in dentistry specially in Periodontology to manage severe bone destruction and attachment loss. PRF is easier to make and less expensive. PRF has also been found to have an antimicrobial function due to the presence of leukocytes.(86) As a result, when PRF was compared to other growth factors, considerably improved clinical radiographic outcomes were reported. Before regenerative surgery with PRF, systemic diseases should exclude to get better prognosis. Different types systemic diseases, aggravate periodontal diseases are more significant in Bangladesh.

Some meta-analysis report that, Bangladesh has a relatively high prevalence of pre-diabetes (10.1\%) and diabetes (7.8\%), with a notable variation between rural and urban areas. (87)

Diabetic patients are more likely to develop various oral diseases $(88,89)$. The most common of these oral health problems is periodontal disease, which has been labeled "the sixth complication of diabetes" (90). Several studies have found that diabetics have a higher prevalence and severity of periodontal disease than non-diabetic persons $(91,92)$. A recent single-center hospital-based study in Bangladesh revealed that individuals with diabetes had a greater prevalence of periodontal disease (55.8\%) (93)

Periodontal regenerative surgery in uncontrolled diabetes should be controlled or adjunctive systemic antimicrobial therapy may improve the prognosis.(94)

Other systemic diseases such as osteoporosis, thyroid and parathyroid problems should be considered before undergoing this type of surgery, and smoking (95) may also have a role in the prognosis of periodontal regenerative surgery.

In Bangladesh, there are just a few case studies on regenerative surgery with PRF membrane in dentistry. No original study has been found on this subject. Because there are so many patients available, an interventional research should be conducted to determine the prognosis and identify other factors that contribute to healing and future advance applications of PRF in different arena of dentistry in

Website: https://www.banglajol.info/index.php/UpDCJ 


\section{Bangladesh.}

\section{CONCLUSSION}

PRF has been shown in studies to have a safe and beneficial effect on hard and soft tissue healing in periodontal surgery. Under proper manipulation, current evidence-based dentistry reveals that PRF can be utilized routinely in periodontal regenerative surgery with good biological effects and appropriate clinical results. PRF's beneficial effects allow it to be used in diverse dental fields in Bangladesh with additional study.

\section{CONFLICT OF INTEREST: None}

\section{Citation:}

Md. Ashif Iqbal, Marjana Hossain Mim, \& Nayna Binte Shahabuddin. Platelet-rich fibrin to manage different periodontal defects combine with Flap surgery and other uses in dentistry. A descriptive review. Update Dental College Journal, 11(2), 43-51 Retrieved from https://www.banglajol.info/index.php/UpDCJ/article/view/56130 DOI:https://doi.org/10.3329/updcj.v11i2.56130

\section{REFERNCES:}

1. Population, total - Bangladesh | Data [Internet]. [cited 2021 Aug 20]. Available from: https://data.worldbank.org/indicator/SP.POP.TOTL?locations=BD

2. Population by Country (2021) - Worldometer [Internet]. [cited 2021 Aug 20]. Available from: https://www.worldometers.info/worldpopulation/population-by-country/

3. Iqbal MA, Mohol J, Afrin F, Khaleque MA, Johra FT, Jannat $\mathrm{N}$. Prevalence of periodontal diseases among the patient visiting at Periodontology OPD Update Dental College Hospital, Dhaka. Updat Dent Coll J. 2016;5(2):23-9.

4. Mahmudul Hasan SM, Rahman M, Nakamura K, Tashiro Y, Miyashita A, Seino K. Relationship between diabetes self-care practices and control of periodontal disease among type 2 diabetes patients in Bangladesh. PLoS One [Internet]. 2021;16(4 April):1-19. Available from: http://dx.doi.org/10.1371/journal.pone.0249011

5. Shirzaiy M, Neshat F. Effect of Areca Nut on Oral Health: A Review. J Res Dent Maxillofac Sci [Internet]. 2020 Aug 1 [cited 2021 Aug 20];5(3):1-6. Available from: http://jrdms.dentaliau.ac.ir/article-1276-en.html

6. Suchana SA, Khalil M. A Survey on Risk Factors, Common Treatment Pattern of Periodontal Disease \& Behavioral Impact of People on this Disease in Dhaka City Submitted By Supervised By. 2016; Available from: http://lib.ewubd.edu:8080/handle/123456789/2227

7. Cardaropoli D, Tamagnone L, Roffredo A, Gaveglio L. Treatment of Gingival Recession Defects Using Coronally Advanced Flap With a Porcine Collagen Matrix Compared to Coronally Advanced Flap With Connective Tissue Graft: A Randomized Controlled Clinical Trial. J Periodontol. 2012 Mar;83(3):321-8.

8. Tonetti MS, Cortellini P, Pellegrini G, Nieri M, Bonaccini D, Allegri M, et al. Xenogenic collagen matrix or autologous connective tissue graft as adjunct to coronally advanced flaps for coverage of multiple adjacent gingival recession: Randomized trial assessing noninferiority in root coverage and superiority in oral health-related quality of life. J Clin Periodontol [Internet]. 2018 Jan 1 [cited 2021 Aug 20];45(1):78. Available from:/pmc/articles/PMC5765511/

9. McGuire MK, Scheyer ET. Long-Term Results Comparing Xenogeneic Collagen Matrix and Autogenous Connective Tissue Grafts With

48| $P$ a g e
10.

Coronally Advanced Flaps for Treatment of Dehiscence-Type Recession Defects. J Periodontol. 2016 Mar;87(3):221-7.

Wachtel H, Schenk G, Böhm S, Weng D, Zuhr O, Hürzeler MB. Microsurgical access flap and enamel matrix derivative for the treatment of periodontal intrabony defects: A controlled clinical study. J Clin Periodontol. 2003 Jun;30(6):496-504.

11. McGuire MK, Scheyer ET. Xenogeneic Collagen Matrix With Coronally Advanced Flap Compared to Connective Tissue With Coronally Advanced Flap for the Treatment of Dehiscence-Type Recession Defects. J Periodontol. 2010 Aug;81(8):1108-17.

12. Tonetti MS, Jepsen S. Clinical efficacy of periodontal plastic surgery procedures: Consensus Report of Group 2 of the 10th European Workshop on Periodontology. J Clin Periodontol. 2014 Apr 1;41:S3643.

13. Zahid TM, Nadershah M. Effect of advanced platelet-rich fibrin on wound healing after third molar extraction: A split-mouth randomized double-blind study. J Contemp Dent Pract. 2019;20(10):1164-70.

14. Su N-YY, Yang L-CC, Chang Y-CC. Platelet-rich fibrin is the first-line treatment option for periodontal regeneration. J Dent Sci [Internet]. 2017 Sep 1 [cited 2021 Aug 20];12(3):203-4. Available from: /pmc/articles/PMC6399993/

15. $\mathrm{YH}, \mathrm{JC}, \mathrm{Y} \mathrm{H}, \mathrm{Q}, \mathrm{P}, \mathrm{M}$ N. Local Application of Platelet-Rich Fibrin During Lower Third Molar Extraction Improves Treatment Outcomes. J Oral Maxillofac Surg [Internet]. 2017 Dec 1 [cited 2021 Aug 20];75(12):2497-506. Available from: https://pubmed.ncbi.nlm.nih.gov/28672135/

16. Dohan DM, Choukroun J, Diss A, Dohan SL, Dohan AJJ, Mouhyi J, et al. Platelet-rich fibrin (PRF): A second-generation platelet concentrate. Part I: Technological concepts and evolution. Oral Surgery, Oral Med Oral Pathol Oral Radiol Endodontology [Internet]. 2006 [cited 2021 Aug 21];101(3). Available from: https://pubmed.ncbi.nlm.nih.gov/16504849/

17. JW G, PM N. Fibrin glue: the perfect operative sealant? Transfusion [Internet]. 1990 [cited 2021 Aug 21];30(8):741-7. Available from: https://pubmed.ncbi.nlm.nih.gov/2219264/

18. Anitua E, Andia I, Ardanza B, Nurden P, Nurden AT. Autologous platelets as a source of proteins for healing and tissue regeneration. Thromb Haemost [Internet]. 2017 Nov 30 [cited 2021 Aug 21];91(01):4-15. Available from: http://www.thiemeconnect.de/products/ejournals/html/10.1160/TH03-07-0440

19. EBSCOhost | 36846167 | Is Platelet-rich Plasma the Perfect Enhancement Factor? A Current Review. [Internet]. [cited 2021 Aug 21]. Available from https://web.a.ebscohost.com/abstract?direct=true\&profile=ehost \&scope $=$ site \&authtype $=$ crawler $\&$ jrnl $=08822786 \& A N=36846167 \& \mathrm{~h}$ =z7baTmll18Pwarl74wU663g\%2FI6RN\%2BHNmCL8qH7\%2FQsKI06Z hlo\%2FVE3OpoddbDxNi\%2BPNvOwn5NcliHc6Nqbncm1w\%3D\%3D \&crl=c\&resultNs=AdminWebAuth\&resultLocal=ErrCrINotAuth\&crlh ashurl=login.aspx\%3Fdirect\%3Dtrue\%26profile\%3Dehost\%26scope \%3Dsite\%26authtype\%3Dcrawler\%26jrnl\%3D08822786\%26AN\%3D 36846167

20. Preeja C, Arun S. Platelet-rich fibrin: Its role in periodontal regeneration. Saudi J Dent Res. 2014 Jul 1;5(2):117-22.

21. Platelet Rich Fibrin in Regenerative Dentistry: Biological Background and Clinical Indications [Internet]. Platelet Rich Fibrin in Regenerative Dentistry: Biological Background and Clinical Indications. 2017 [cited 2021 Aug 22]. Available from: https://books.google.com.bd/books?hl=en\&lr=\&id=aEozDwAAQBA $J \&$ oi=fnd\&pg=PR13\&dq=use+of+prf+in+dentistry\&ots=siydXIWnP6 \&sig=TFeybw6L7odcZnx7wKz3_Z-k-

$\mathrm{xY} \&$ redir_esc $=\mathrm{y} \# \mathrm{v}=$ onepage \&q=use of prf in dentistry\& $\mathrm{f}=$ false

22. Choukroun: PRF: an opportunity in perio-implantology - Google Scholar [Internet]. [cited 2021 Aug 21]. Available from: https://scholar.google.com/scholar_lookup?title=PRF\%3A an

Website: https://www.banglajol.info/index.php/UpDCJ 
opportunity in perio-implantology\&author=J. Choukroun\&publication_year $=2000$ \&pages $=55-62$

23.

, second-generation platelet concentrate. Part I: technological concepts and evolution. Oral Surg Oral Med Oral Pathol Oral Radiol Endod [Internet]. 2006 [cited 2021 Aug 21];101(3). Available from: https://pubmed.ncbi.nlm.nih.gov/16504849/

24. Chang YC, Wu KC, Zhao JH. Clinical application of platelet-rich fibrin as the sole grafting material in periodontal intrabony defects. J Dent Sci [Internet]. 2011;6(3):181-8. Available from: http://dx.doi.org/10.1016/j.jds.2011.05.010

25. Merizalde G, Lopera D, Villegas M, Restrepo LM. Leucocyte Platelet Rich Fibrin with Autologous Gingival Fibroblasts in the Treatment of Adjacent Recession Defects. Int J Odontostomatol. 2019;13(1):2330.

26. Su NY, Yang LC, Chang YC. Platelet-rich fibrin is the first-line treatment option for periodontal regeneration. J Dent Sci. 2017;12(3):203-4.

27. Su NY, Chang YC. Clinical application of platelet-rich fibrin in perioendo combined intrabony defect. J Dent Sci. 2015;10(4):462-3.

28. Kobayashi E, Flückiger L, Fujioka-Kobayashi M, Sawada K, Sculean A Schaller B, et al. Comparative release of growth factors from PRP, PRF, and advanced-PRF. Clin Oral Investig 2016209 [Internet]. 2016 Jan 25 [cited 2021 Aug 27];20(9):2353-60. Available from: https://link.springer.com/article/10.1007/s00784-016-1719-1

29. Kobayashi M, Kawase T, Horimizu M, Okuda K, Wolff LF, Yoshie H. A proposed protocol for the standardized preparation of PRF membranes for clinical use. Biologicals. 2012 Sep 1;40(5):323-9.

30. Open access information - Biologicals - ISSN 1045-1056 [Internet]. [cited 2021 Aug 28]. Available from: https://www.elsevier.com/journals/biologicals/1045-1056/openaccess-options

31. Crisci A, Lombardi D, Serra E, Lombardi G, Cardillo F, Crisci M. Standardized protocol proposed for clinical use of L-PRF and the use of L-PRF Wound Box ${ }^{\circledR}$. J Unexplored Med Data. 2017;2(2):77.

32. Creative Commons - Attribution 4.0 International - CC BY 4.0 [Internet]. [cited 2021 Aug 28]. Available from: https://creativecommons.org/licenses/by/4.0/

33. V SR, E MN. Platelet-rich fibrin: evolution of a second-generation platelet concentrate. Indian J Dent Res [Internet]. 2008 Jan 1 [cited 2021 Aug 20];19(1):42-6. Available from: https://pubmed.ncbi.nlm.nih.gov/18245923/

34. Naik B, Karunakar P, Jayadev M, Marshal VR. Role of Platelet rich fibrin in wound healing: A critical review. J Conserv Dent [Internet]. 2013 Jul [cited 2021 Aug 20];16(4):284. Available from: /pmc/articles/PMC3740636/

35. D K, A F, VM D, MK A. Effect of autologous platelet rich fibrin on the healing of experimental articular cartilage defects of the knee in an animal model. Biomed Res Int [Internet]. 2014 [cited 2021 Aug 20];2014. Available from: https://pubmed.ncbi.nlm.nih.gov/25028656/

36. Pawar AM, Pawar SM, Thakur B, Kokate S. Successful Surgical Outcome for an Endodontic Failure using BiodentineTM as Retrograde Restoration in Conjunction with Platelet Rich Fibrin (PRF) for Progressive Healing. J Clin Diagn Res [Internet]. 2017 Apr 1 [cited 2021 Aug 20];11(4):ZJ03. Available from: /pmc/articles/PMC5449948/

37. Pinto NR, Ubilla M, Zamora Y, Rio V Del, Ehrenfest DMD, Quirynen $M$. Leucocyte- and platelet-rich fibrin (L-PRF) as a regenerative medicine strategy for the treatment of refractory leg ulcers: a prospective cohort study. https://doi.org/101080/0953710420171327654 [Internet]. 2017 Jul 4 [cited 2021 Aug 20];29(5):468-75. Available from: https://www.tandfonline.com/doi/abs/10.1080/09537104.2017.13 27654
38.

Wang Z, Weng Y, Lu S, Zong C, Qiu J, Liu Y, et al. Osteoblastic mesenchymal stem cell sheet combined with Choukroun plateletrich fibrin induces bone formation at an ectopic site. J Biomed Mater Res Part B Appl Biomater [Internet]. 2015 Aug 1 [cited 2021 Aug 20];103(6):1204-16. Available from: https://onlinelibrary.wiley.com/doi/full/10.1002/jbm.b.33288 Chien C-S, Ho H-O, Liang $\mathrm{Y}-\mathrm{C}$, Ko $\mathrm{P}-\mathrm{H}$, Sheu M-T, Chen $\mathrm{C}-\mathrm{H}$ Incorporation of exudates of human platelet-rich fibrin gel in biodegradable fibrin scaffolds for tissue engineering of cartilage. J Biomed Mater Res Part B Appl Biomater [Internet]. 2012 May 1 [cited 2021 Aug 20];100B(4):948-55. Available from: https://onlinelibrary.wiley.com/doi/full/10.1002/jbm.b.32657

40. Beitzel K, McCarthy MB, Cote MP, Russell RP, Apostolakos J, Ramos $D M$, et al. Properties of Biologic Scaffolds and Their Response to Mesenchymal Stem Cells. Arthrosc J Arthrosc Relat Surg. 2014 Mar 1;30(3):289-98.

41. Temmerman A, Cleeren GJ, Castro AB, Teughels W, Quirynen M. LPRF for increasing the width of keratinized mucosa around implants: A split-mouth, randomized, controlled pilot clinical trial. J Periodontal Res [Internet]. 2018 Oct 1 [cited 2021 Aug 20];53(5):793-800. Available from: https://onlinelibrary.wiley.com/doi/full/10.1111/jre.12568

42. Sameera S, Nagasri M, Aravind Kumar $P$, Indeevar $P$, Raviraj K, Musalaiah SVVS. Comparison of two surgical techniques in the treatment of multiple gingival recessions sandwiched with a combination of A-PRF and L-PRF. Saudi Dent J. 2018 Jul 1;30(3):1839.

43. Öncü E. The Use of Platelet-Rich Fibrin Versus Subepithelial Connective Tissue Graft in Treatment of Multiple Gingival Recessions: A Randomized Clinical Trial. Int J Periodontics Restorative Dent. 2017;37(2):265-71.

44. Garzon HS, Alfonso C, Vega FJ, García A, Muñoz A, Jaimes G, et al. Treatment of Miller I mandibular gingival recessions using PRF vs. connective graft. Int J Dent. 2021;2021.

45. Anilkumar K, Geetha A, Umasudhakar, Ramakrishnan T, Vijayalakshmi R, Pameela E. Platelet-rich-fibrin: A novel root coverage approach. J Indian Soc Periodontol [Internet]. 2009 [cited 2021 Aug 22];13(1):50. Available from: /pmc/articles/PMC2846677/

46. Aroca S, Keglevich T, Barbieri B, Gera I, Etienne D. Clinical Evaluation of a Modified Coronally Advanced Flap Alone or in Combination With a Platelet-Rich Fibrin Membrane for the Treatment of Adjacent Multiple Gingival Recessions: A 6-Month Study. J Periodontol [Internet]. 2009 Feb 1 [cited 2021 Aug 22];80(2):244-52. Available from:

https://aap.onlinelibrary.wiley.com/doi/full/10.1902/jop.2009.080 253

47. Committee IE, Dentistry P, Sciences M. Evaluation of Platelet Rich Fibrin in Comparison With Bone Graft For Treating Furcation Defects In Chronic Periodontitis: A Systematic Review Protocol. 2019;6(6):806-12.

48. Alsayed I, Abousulaiman A, Jawish A Al, Alsabbagh MM. Journal of International Dental and Medical Research ISSN 1309-100X http://www.jidmr.com Use of Platelet-Rich Fibrin in Socket Preservation lyad Alsayed, and et al. 2001;

49. Panda S, Karanxha L, Goker F, Satpathy A, Taschieri S, Francetti L, et al. Autologous Platelet Concentrates in Treatment of Furcation Defects - A Systematic Review and Meta-Analysis.

50. Goel A, Hamada Y, Windsor LJ, Gregory RL, Blanchard SB. Effects of platelet-rich fibrin on human gingival and periodontal ligament fibroblast proliferation from chronic periodontitis versus periodontally healthy subjects. 2020;(November):1-7.

51. Aggour RL, El-hady HMGA. Platelet-Rich Fibrin for the Treatment of Intrabony Periodontal Defects in Patients with Generalized Aggressive Periodontitis : A Randomized Controlled Clinical Study. 2019;(January 2017).

Website: https://www.banglajol.info/index.php/UpDCJ 
52. Lei L, Yu Y, Han J, Shi D, Sun W, Zhang D. Title Page Quantification of growth factors in advanced platelet-rich fibrin and concentrated growth factors and their clinical efficiency as adjunctive to the GTR procedure in periodontal intrabony defects Abstract :

53. Csifo-nagy BK, Solyom E. E cacy of a New-generation Platelet-rich Fibrin in the Treatment of Periodontal Intrabony Defects: a Randomized Clinical Trial. :1-20.

54. Zhou S, Sun C, Huang S, Wu X, Zhao Y, Pan C, et al. Efficacy of Adjunctive Bioactive Materials in the Treatment of Periodontal Intrabony Defects: A Systematic Review and Meta-Analysis. 2018;2018.

55. Natto ZS, Green MS. SC. J Evid Based Dent Pract. 2017;

56. Duan X, Lin Z, Lin X, Wang Z, Wu Y, Ji M, et al. Study of platelet-rich fibrin combined with rat periodontal ligament stem cells in periodontal tissue regeneration. 2018;22(2):1047-55.

57. Jiang P, Pan J, Liu C, Zheng L. Synergistic Application of Platelet-Rich Fibrin and $1 \%$ Alendronate in Periodontal Bone Regeneration : A Meta-Analysis. 2019;2019.

58. i-PRF a Boon In Regenerative Periodontal Therapy : A Case Report of 1- Year Follow-Up. 2020;1300:582-6.

59. Krishnamurthi T, Hospitals B. differentiation and promotes apoptosis by the intrinsic mitochondrial Platelet-rich fibrin / biphasic calcium phosphate impairs osteoclasts differentiation and promotes apoptosis by the intrinsic mitochondrial pathway in chronic periodontitis. 2018;(July).

60. Lei L, Yu Y. The Application of Three-Dimensional Printing Model and Platelet-Rich Fibrin Technology in Guided Tissue Regeneration Surgery for Severe Bone Defects.

61. Horimizu M, Kobayashi M, Nakata K. Synergistic effects of the combined use of human - cultured periosteal sheets and platelet rich fibrin on bone regeneration : An animal study. 2017;(May):13441.

62. Kargarpour Z, Nasirzade J, Strauss FJ, Gruber R, Hasannia S, Müller $\mathrm{H}$. Platelet-rich fibrin suppresses in vitro osteoclastogenesis. 2020;(July 2019):413-21.

63. Creative Commons - Attribution-NonCommercial 4.0 International - CC BY-NC 4.0 [Internet]. [cited 2021 Aug 28]. Available from: https://creativecommons.org/licenses/by-nc/4.0/deed.en

64. Open access information - Journal of Dental Sciences - ISSN 19917902 [Internet]. [cited 2021 Aug 28]. Available from: https://www.elsevier.com/journals/journal-of-dental-

sciences/1991-7902/open-access-journal

65. Halawani SM, Hamdi BN, Abdullah M. The role of platelet-rich fibrin ( PRF ) in periodontology. 2019;3(February):214-8.

66. Paul S, Choudhury R, Kumari N, Rastogi S, Sharma A, Singh V, et al. Is treatment with platelet-rich fibrin better than zinc oxide eugenol in cases of established dry socket for controlling pain, reducing inflammation, and improving wound healing? J Korean Assoc Oral Maxillofac Surg [Internet]. 2019 Apr 29 [cited 2021 Aug 23];45(2):76-82. Available from: https://synapse.koreamed.org/articles/1121843

67. Feigin K, Avdc D, Shope B, Avdc D. Use of Platelet-Rich Plasma and Platelet- Rich Fibrin in Dentistry and Oral Surgery : Introduction and Review of the Literature. 2019;36(2):109-23.

68. Mello-machado RC De, Fernando C, Barros DA, Javid K, Moraschini $V$. The use of leukocyte- and platelet-rich fi brin in the management of soft tissue healing and pain in post-extraction sockets: A randomized clinical trial. 2020;48:452-7.

69. Narayan S, Malaiappan S. Tetracycline Combined With PRF Membrane In A Periodontal Compromised Splinted Incisor To Enhances Soft Tissue Support Despite Poor Oral Hygiene: A Case Report With 1 Year Follow-Up Tetracycline Combined With PRF Membrane In A Periodontal Compromised Spli. 2021;(July).

70. Soni R, Priya A, Yadav H, Kumar V. Utilizing autologous growth factors enriched bone graft matrix ( sticky bone ) and Platelet rich

50이 a g e fibrin ( PRF ) membrane to enable dental implant placement : A case report. 2019;5(1):16-9.

71. Cleeren GJ, Quirynen WTM. L--PRF for increasing the width of keratinized mucosa around implants : A split--mouth, randomized, controlled pilot clinical trial. 2018;(March).

72. Kotsakis GA, Boufidou F, Hinrichs JE, Prasad HS, Rohrer M, Tosios KI. Extraction Socket Management Utilizing Platelet Rich Fibrin: A Proofof-Principle Study of the "Accelerated-Early Implant Placement" Concept. J Oral Implantol [Internet]. 2016 Apr 1 [cited 2021 Aug 24];42(2):164-8. Available from: http://meridian.allenpress.com/joi/articlepdf/42/2/164/2039453/aaid-joi-d-15-00001.pdf

73. Bone G, Case RA, Byrappa B, Ranganatha N, Yunus M, Raman R. CASE REPORT SURGICAL MANAGEMENT OF INFECTED RADICULAR CYST USING PLATELET RICH FIBRIN ( PRF ), SYNTHETIC BONE GRAFT AND PERIODONTAL MEMBRANE FOR. 2018;05(04):3787-92.

74. Lin J, Zeng Q, Wei X, Zhao W, Cui M, Gu J, et al. Regenerative Endodontics Versus Apexification in Immature Permanent Teeth with Apical Periodontitis: A Prospective Randomized. J Endod. 2017;1-7.

75. Ghanaati S, Herrera-Vizcaino C, Al-Maawi S, Lorenz J, Miron RJ, Nelson K, et al. Fifteen Years of Platelet Rich Fibrin in Dentistry and Oromaxillofacial Surgery: How High is the Level of Scientific Evidence? J Oral Implantol [Internet]. 2018 Dec 1 [cited 2021 Aug 23];44(6):471-92. Available from: http://meridian.allenpress.com/joi/articlepdf/44/6/471/2033981/aaid-joi-d-17-00179.pdf

76. Azzaldeen A, Mai A, Muhamad A. Platelet-rich fibrin ( PRF ) in dentistry. 2019;5(4):1-8.

77. Sultan T, Pachisia SK, Banerjee R, Sahu S, Bose A. Platelet-rich Fibrin and its Application in Dentistry: An Institutional Experience. 2017;2017(3):171-5.

78. Gehlot PM, Khurana S, Jayadevan V. Short Communication Nonsurgical endodontic management of furcation perforation using Advanced Platelet-rich Fibrin as an internal matrix and Biodentine : A clinical report with. 2020;(September).

79. P K, JS P, M J, GS S. Platelet-rich fibrin, "a faster healing aid" in the treatment of combined lesions: A report of two cases. J Indian Soc Periodontol [Internet]. 2014 Sep 1 [cited 2021 Aug 23];18(5):651-5. Available from: https://pubmed.ncbi.nlm.nih.gov/25425831/

80. $\mathrm{H} \mathrm{E}-\mathrm{S}, \mathrm{A} \mathrm{K}, \mathrm{J} \mathrm{D}, \mathrm{H} \mathrm{H}, \mathrm{H} \mathrm{L}, \mathrm{M} \mathrm{A}$, et al. Platelet-rich plasma: growth factors and pro- and anti-inflammatory properties. J Periodontol [Internet]. 2007 Apr [cited 2021 Aug 23];78(4):661-9. Available from: https://pubmed.ncbi.nlm.nih.gov/17397313/

81. Nagar P, Viswanath D. Platelet Rich Plasma / Platelet Rich FibrinUses in Pediatric Dentistry : A Review. 2012;43-6.

82. NS I, BJ C, KW S, YJ L, BS L, SH K. Single-Tooth Osteotomy Combined Wide Linear Corticotomy Under Local Anesthesia for Correcting Anterior Protrusion With Ectopically Erupted Canine. J Craniofac Surg [Internet]. 2017 [cited 2021 Aug 24];28(1):e30-3. Available from: https://pubmed.ncbi.nlm.nih.gov/27875512/

83. V L, I M, Z A, S J, P S, EB K, et al. Platelet-rich fibrin and bovine porous bone mineral vs. platelet-rich fibrin in the treatment of intrabony periodontal defects. J Periodontal Res [Internet]. 2012 Aug [cited 2021 Aug 25];47(4):409-17. Available from: https://pubmed.ncbi.nlm.nih.gov/22126591/

84. Najeeb S, Khurshid Z, Agwan MAS, Ansari SA, Zafar MS, Matinlinna JP. Regenerative Potential of Platelet Rich Fibrin (PRF) for Curing Intrabony Periodontal Defects: A Systematic Review of Clinical Studies. Tissue Eng Regen Med. 2017;14(6):735-42.

85. Miron RJ, Moraschini V, Del Fabbro M, Piattelli A, Fujioka-Kobayashi $M$, Zhang $Y$, et al. Use of platelet-rich fibrin for the treatment of gingival recessions: a systematic review and meta-analysis. Clin Oral Investig 2020248 [Internet]. 2020 Jun 26 [cited 2021 Aug 22];24(8):2543-57. Available from: Website: https://www.banglajol.info/index.php/UpDC」 
https://link.springer.com/article/10.1007/s00784-020-03400-7

86. TM B, TS G, J A, T S, W K, T W. Antibacterial effect of autologous platelet gel enriched with growth factors and other active substances: an in vitro study. J Bone Joint Surg Br [Internet]. 2007 Mar [cited 2021 Aug 27];89(3):417-20. Available from: https://pubmed.ncbi.nlm.nih.gov/17356164/

87. Akhtar S, Nasir JA, Sarwar A, Nasr N, Javed A, Majeed R, et al. Prevalence of diabetes and pre-diabetes in Bangladesh: a systematic review and meta-analysis. BMJ Open [Internet]. 2020 Sep 1 [cited 2021 Aug 27];10(9):e036086. Available from: https://bmjopen.bmj.com/content/10/9/e036086

88. MJL V, BG L, VEA G, WJ T. Evaluating All Potential Oral Complications of Diabetes Mellitus. Front Endocrinol (Lausanne) [Internet]. 2019 [cited 2021 Aug 27];10(FEB). Available from: https://pubmed.ncbi.nlm.nih.gov/30962800/

89. IB L, E L, WS B, GW T. The relationship between oral health and diabetes mellitus. J Am Dent Assoc [Internet]. 2008 [cited 2021 Aug 27];139 Suppl(10 SUPPL.):19S-24S. Available from: https://pubmed.ncbi.nlm.nih.gov/18809650/

90. Löe H. Periodontal Disease: The sixth complication of diabetes mellitus. Diabetes Care [Internet]. 1993 Jan 1 [cited 2021 Aug 27];16(1):329-34. Available from: https://care.diabetesjournals.org/content/16/1/329

91. $\mathrm{M} \mathrm{H}, \mathrm{HY}$ K, H S, CD Y, YS K, JY S, et al. Prevalence and risk factors of periodontitis among adults with or without diabetes mellitus. Korean J Intern Med [Internet]. 2016 Sep 1 [cited 2021 Aug 27];31(5):910-9. Available from: https://pubmed.ncbi.nlm.nih.gov/27604799/

92. KY N, AM O, RK C, VJ A. Chronic periodontitis among diabetics and nondiabetics aged 35-65 years, in a rural block in Vellore, Tamil Nadu: A cross-sectional study. J Indian Soc Periodontol [Internet]. 2017 Jul 1 [cited 2021 Aug 27];21(4):309-14. Available from: https://pubmed.ncbi.nIm.nih.gov/29456306/

93. Mahmud SZ, Alif SM, Tarafder MA, Hossain SM. The Correlation between Periodontal Diseases and Chronological Age among Type 2 Diabetes Mellitus Patients attending at National Healthcare Network (NHN) Mirpur Centre, Dhaka, Bangladesh. BIRDEM Med J [Internet]. 2013 Dec 1 [cited 2021 Aug 27];3(2):74-69. Available from:

https://www.banglajol.info/index.php/BIRDEM/article/view/17209

94. Promsudthi A, Pimapansri S, Deerochanawong C, Kanchanavasita W. The effect of periodontal therapy on uncontrolled type 2 diabetes mellitus in older subjects. Oral Dis [Internet]. 2005 Sep 1 [cited 2021 Aug 27];11(5):293-8. Available from: https://onlinelibrary.wiley.com/doi/full/10.1111/j.16010825.2005.01119.x

95. Heasman L, Stacey F, Preshaw PM, McCracken GI, Hepburn S, Heasman PA. The effect of smoking on periodontal treatment response: a review of clinical evidence. J Clin Periodontol [Internet]. 2006 Apr 1 [cited 2021 Aug 27];33(4):241-53. Available from: https://onlinelibrary.wiley.com/doi/full/10.1111/j.1600-

051X.2006.00902.x

51| $P$ a g e 